\title{
KORUNMAYA MUHTAÇ ÇOCUKLAR VE KORUNMAYA MUHTAÇ ÇOCUKLARA SAĞLANAN BAKIM YÖNTEMLERİ
}

\author{
Öğr. Gör. Barış TUNCER ${ }^{1}$ \\ Öğr. Gör. Tuğba ERDOĞAN ${ }^{2}$
}

\begin{abstract}
Özet
Dünyada korunmaya muhtaç çocuklar için düzenlenen koruma ve bakım sistemleri bir değişim sürecinden geçmektedir. Kurum bakımının olumsuz yönlerinin ortaya çıkmasından sonra çocuğun aile yanında bakım ve korunmasının sağlandığı hizmet modellerine ağılık verilmeye başlanmıştır. Ülkemizde de bu değişim sürecini etkisiyle korunmaya muhtaç çocuklar için hizmet veren büyük kurumların bazıları kapatılmış, bazılarının da kapasiteleri azaltılmıştır. Ülkemizde çocuğun aile yanında bakım ve korunmasının sağlandığı, bunun mümkün olmadığı durumlarda ise az sayıda çocuğa koruma ve bakım hizmeti veren hizmet modelleri öncelikli olarak tercih edilmeye başlanmıştır. Kurum bakımı açısından çok sayıda çocuğa hizmet veren büyük kurumların yerini daha az sayıda çocuğun bakım ve korunmasının sağlandığı hizmet modellerine geçilmesi önemli bir gelişmedir. $\mathrm{Bu}$ çalışmada ülkemizde korunmaya muhtaç çocuklara bütün hizmet modelleri kısaca tanıtılmış ve koruma ve bakım hizmetlerinin bir değerlendirilmesine yer verilmiştir. Bu çalışma literatür taramasına dayalı nitel bir çalışmadır. Araştırma sonucunda, evlat edindirme ve koruyucu aile uygulaması hizmetlerinden yararlandırılan çocuk sayısının hala çok düşük olduğu ve son yıllarda bu hizmetlerdeki olumlu gelişmelere rağmen istenilen düzeye ulaşılamadığı ve toplumun bu hizmet modellerine karşı olumsuz bir tutumunun olduğu ortaya çıkmıştır. $\mathrm{Bu}$ olumsuz tutumun değiştirilmesi ve bu uygulamalardan daha çok çocuğun yararlanabilmesi için topluma yönelik eğitim ve rehberlik çalışmaları yapılmalıdır. Bunun yanında ülkemizde çocukların kurum bakımına alınma nedenlerinin başında ekonomik nedenlerin geldiği, çocuğun aile yanında desteklenmesi ile bu durumun engellenebileceği ancak ekonomik desteklerin günümüz koşullarında yetersiz kaldığı ve artırılması gerektiği görülmüştür.
\end{abstract}

Anahtar Kelimeler: Korunmaya muhtaç çocuk, Çocuk koruma ve bakım sistemi

\section{PROTECTIVE CHILDREN AND PROTECTIVECHILDREN PROTECTION PROVIDED TO CHILDREN}

\begin{abstract}
Protection and care systems for children in need of protection in the world are undergoing an exchange process. After the adverse aspects of the care of the institution have emerged, emphasis has been given to the service models that are provided for the care and protection of the child in the family. In our country, some of the large institutions that provide services for children in need of protection under the influence of this transformation process have been closed down and some have been reduced in their capacities. In cases where it is not possible for our country to provide care and protection for the homeland of the child, service models that provide protection and care services for a small number of children have begun to be preferred in the first place. In terms of institutional care, it is important to replace large institutions that serve a large number of children with service models where fewer children are maintained and protected. In this study, all service models were briefly introduced to children in need of protection in our country and an assessment of protection and care services was given. This is a qualitative study based on literature review. As a result of the research, it is found out that the number of children benefiting from adoption and preventive family practice services is still very low, and despite the positive developments in these services in recent years, the desired level has not been reached and the society has been found to be a negative attitude towards these service models. In order for this negative attitude to be changed and more children to benefit from these practices, collective education and guidance work should be done. Besides, it has been seen that economic reasons are the main causes of the institutionalization of children in our country and that this situation can be prevented with the support of the child in the family, but the economic supports should be insufficient and increased in today's conditions.
\end{abstract}

Keywords: Children in need of protection, Child protection and care system

Derleme Makale / Review Article

${ }^{1}$ Sorumlu yazar/Corresponding Author, Altınbaş Üniversitesi, Türkiye, barıs.tuncer@altinbas.edu.tr, ORCID ID: 0000000236692606. ${ }^{2}$ Altınbaş Üniversitesi, Türkiye, tugba.erdogan@altinbas.edu.tr, ORCID ID: 0000000150303796. 


\section{GíRIş}

Ülkemiz çok hızlı bir toplumsal değişim süreci geçirmekte ve bu durum çeşitli sosyal sorunları da beraberinde getirmektedir. İşsizlik, yoksulluk, kırsal bölgelerden kente göç, çarpık kentleşme, parçalanmış aile sayısındaki artış, bireysel ve toplumsal şiddet, alkol ve madde bağımlılı̆̆ı, ruh sağlı̆̆ı sorunları bu sorunlar arasında yer almaktadır. Yaşanan hızlı toplumsal değişim süreci ve bunun sonucunda ortaya çıkan toplumsal sorunlar, toplum içerisinde en fazla dezavantajlı grupları etkilemektedir. Dezavantajlı gruplar içinde yer alan çocuklar, bu hızlı değişim süreci ve onun ortaya çıkardığı sorunlara karşı savunmasız ve güçsüz durumdadır. Özellikle ailenin parçalanması, ebeveynlerin ruhsal sorunları, alkol ve madde bağımlığı, yoksulluk gibi sorunlar çocukları olumsuz etkilemekte ve korunmaya muhtaç çocuk sayısı artmaktadır. Suça sürüklenen çocuklar, sokakta yaşayan ve sokakta çalışan çocuklar, alkol ve madde bağımlılı̆̆ sorunlar arasındadır. Korunmaya muhtaç çocuklar sorunu tarihin her döneminde var olan bir sosyal sorundur. Her dönemde toplumlar bu sorunu çözebilmek ve çocuklara gerekli koruma ve bakımı sağlayabilmek için farklı yöntemlere başvurmuşlardır. Tarihsel süreç içerisinde çocukluk kavramı, korunmaya muhtaç çocuklar sorunu ve bu sorun için geliştirilen çözüm yöntemleri bir değişim geçirmiştir. Sosyal politika ve sosyal çalışma disiplinlerdeki yenilik ve gelişmeler korunmaya muhtaç çocuklar sorunu ve bu sorun için geliştirilen çözüm yöntemlerini de dönüştürmüş ve farklı koruma ve bakım sistemleri ortaya konulmuştur. Ülkemizde bu değişim sürecinden etkilenmiş ve çocuk koruma ve bakım hizmetlerinde zamanla farklı bakım modelleri geliştirilmiştir. Bu çalışmada Türkiye'de korunmaya muhtaç çocuklara sunulan hizmetlerin genel bir görünümü sunulacak, bu hizmetler kısaca tanıtılacak ve bu hizmetlerin genel bir değerlendirmesini yapılacaktır.

\section{Korunmaya Muhtaç Çocuklar}

Sosyal Hizmetler ve Çocuk Esirgeme Kurumu Kanunu'nda, korunmaya muhtaç çocuk beden, ruh ve ahlak gelişimleri veya şahsi güvenlikleri tehlikede olup; annesiz veya babasız, anne veya babası veya her ikisi de belli olmayan, anne veya babası veya her ikisi tarafindan terk edilen, anne veya babası tarafindan ihmal edilip; fuhuş, dilencilik, alkollü içkileri veya uyuşturucu maddeleri kullanma gibi her türlü sosyal tehlikelere ve kötü alışkanlıklara karşı savunmasız bırakılan ve başıboşluğa sürüklenen çocuğu ifade etmektedir (m.3/b).

Her açıdan sağlıklı gelişmesi için gerekli şartların bulunmadığı çocuklar en geniş anlamıyla korunmaya muhtaç çocuklardır. Dar kapsamı ile toplum standartlarına göre tehlikede olan ve durumuna toplumca müdahale edilmesi gereken çocuklar anlaşılmaktadır. Geçmişte daha çok 'kimsesiz ve yoksul çocuklar' kavramı tercih edilirken daha sonra kimsesiz ve yoksul olmayan çocukların da korunmaya ihtiyacı olabileceği düşünülerek bu kavram yerini daha kapsamlı olan korunmaya muhtaç çocuk kavramına bırakmıştır (Koşar, 1992, s.43).

5395 Sayılı Çocuk Koruma Kanunu'nda; Korunma ihtiyacı olan çocuk: Bedensel, zihinsel, ahlaki ve sosyal ve duygusal gelişimi ile kişisel güvenliği tehlikede olan, ihmal ve istismar edilen ya da suç mağduru çocuğu ifade ermektedir.

Şenocak'a göre ise korunmaya muhtaç çocukluk belli bir zaman diliminde, içinde bulunduğu toplumun standartları açısından, çocuğun temel bakımında, yetiştirilmesinde, korunmasında ve gözetilmesinde yetersizlik ve aksaklıklar olması ve bu nedenle çocuğun sosyal, fiziksel, ruhsal ve ahlaki açıdan sağlıklı bir erişkin engellenmesi durumudur. Bedensel gelişimi tamamlanmadığından, anne babası olan veya kimsesi olmayan, varlıklı veya varlıksız, suçlu ya da suçsuz, gibi bireysel farklıkları dikkate alınmadan hukuki açıdan sağ ve tam doğduğu andan başlayarak reşit olduğu zamana kadar her çocuk korunmaya muhtaç çocuk olarak değerlendirilmektedir( Şenocak, 2005; Akt. Doğru \& Saltalı, 2015, s. 234). 
Çocukları etkileyen toplumsal etmenler savaşlar, yoksulluk ve alt toplum kesiminden gelmiş olma belirtilmiştir (Geçtan 1980; Akt. Sargın 2015, s. 43). Yoksulluk ve alt kesimden gelmiş olmanın yarattığı diğer kısıtlamalar çocukta kusurlu gelişimin önemli nedenlerinden biridir. Orta kesimlerdeki ailelerden gelen çocuklarla kıyaslandığında bu çocukların çeşitli gelişim kusurları gösterdikleri saptanmıştır. Alt toplumsal düzeydeki çocuklarda dil yeterince gelişmemektedir. Ayrım yapma ve kavramlaştırma yetenekleri sinırlı kalmaktadır. Bu çocuklarda düşünsel işlevlerde tutukluk ve yavaşlık, sorun çözmede yetersizlik, umutsuzluk ve isteksizlik gibi güdülenme güçlükleri, yetersiz içsel denetim ve dış denetimlere bağımlılık, değersizlik duygularıyla birlikte kızgınlık ve başarısızlık gözlenmiştir (Geçtan, 1980; Akt. Sargın 2015, s. 43). Korunmaya muhtaç çocuklar, bir sistem olarak diğer birçok sistemle ilişki ve sürekli etkileşim içerisindedirler. Bu ilişki sistematiği, çocukların yakın aile çevresini, yaşadığı sosyal çevrede toplumu, yasaları ve uygulanan politikaları kapsamaktadır. Toplumsal ve ekonomik politikalar, yaşanılan çevrenin kültürel özellikler ve aile yaşamı insan hayatını biçimlendirmekte ve sistemde oluşan bir değişme bir diğer alt sistemi ve bütün sistemi etkilemektedir. Bu nedenlerden, sosyal politikaların değişmesi, ebeveynlerden birini kaybetme, aile üyelerinin işsiz kalması, boşanma gibi sistemdeki herhangi bir değişimde ve olumsuz durumda, çocuk da aynı biçimde etkilenecektir. Ekolojik sistem kuramına göre, "korunması gereken çocuklar" sorununu açıklamak için: Ülkemizdeki korunmaya muhtaç çocuklar problemi, toplumsal değişim, sosyoekonomik değişimler, göç, şehirleşme, işsizlik ve yoksulluk gibi toplumsal değişmeye neden olan yapısal faktörlerle ailelerin durumunun ve özelliklerinin (aile yapısı ve işlevleri vb.) etkileşimi sonucu ortaya çıkmaktadır. Toplumsal değişim, göç, şehirleşme, işsizlik ve yoksulluk vb. etkenler hem ailelerini etkilerken hem de onlardan etkilenen durumlar olmuştur (Yolcuoğlu, 2009, s. 45). Görüldüğü gibi insan yaşamını etkileyen bazı negatif değişimler çocukları korunma ortamlarına maruz bırakmaktadırlar.

Korunmaya muhtaç çocukların sağlıklı gelişim süreçlerini engelleyen birçok sorun bulunmaktadır. Ekolojik sistem yaklaşımında; insan ve içinde yaşadığı çevre ile etkileşimi, ailesi ve akrabalarını kapsayan 'mikrosistem'; çocuk için aktif olarak etken olmayıp ancak çocuğun yaşantısı ve gelişimi üzerinde etkili olan kitle iletişim aracı, komşu, akran, sosyal hizmet, okul vb. eğitim kurumu, sağlik, sosyal güvenliğe ilişkin kurum vb. bütün bu sistemlerin kendi içindeki bağlantısını oluşturan 'mezzosistem'; kurumların üst düzeyde sosyoekonomik politikaları ile ülkenin ve toplumun inanç arasınada değer ve ideolojilerini içeren 'makro sistem' çocukların gelişimini pozitif veya negatif şekilde etkilemektedir. Merkezde bulunan çocuk için, ekosistemin farklı görünümleri, ailesi ve akrabaları ile birlikte uyumlu çalıştığında sistem dengededir, böylelikle çocukta gelişim süreci normaldir. Çocukla ekosistem arasındaki uyumsuzluk olduğunda ise çocuğun sağlıklı gelişimi için bazı sorunlar ortaya çıkmaktadır (Yolcuoğlu, 2009, s. 44, 45).

Her sosyal devlet yapısında oluşturulan muhtaç çocuklara kurum bakımı sistemi bulunmaktadır (Carolee, 2013; Wolff, 2009). Çocuk olgusuna yaklaşım ve çocuk refahı politikalarındaki gelişen ilerlemeler çocuk koruma sistemlerinin ortaya çıkmasını sağlamıştır (Yolcuoğlu, 2009, s. 48). Bu iki ülke örneğinde çocuğa, anneye, babaya, aileye hizmetin amacı Türkiye'de erken çocukluk eğitimi için belirlenen okul öncesi eğitimin genel amaç ve ilkeleriyle benzerdir.

\section{Türkiye'de Çocuk Korumanın Tarihsel Gelişimi}

0-18 yaş arası bireylere yasal olarak çocuk denilir. Geniş kapsamda toplumsal, felsefi, ahlaki ve hukuksal boyutları olan çocuk hakları kavramı temelde felsefi yaklaşımla; refah hakları, korumacı hakları, yetişkin hakları, ana-babalara karşı haklar ve hukuksal anlamda çocuk hakları olmak üzere iki yaklaşımla ele alınabilir. Tarihsel dönemde, 1924 yılında Türkiye Cumhuriyeti'nin kurucusu Atatürk'ün de imzaladığı Cenevre Çocuk Hakları Bildirgesi ile başlayan süreç II. Dünya Savaşı ile kesintiye uğramış, uluslararası alanda yapılan çocuk hakları çalışmaları, savaşın sonrasında kurulan Birleşmiş Milletler (BM) örgütünün önderliğinde devam 
etmiştir. 1948 tarihli İnsan Hakları Evrensel Beyannamesi ile 1959 tarihli Birleşmiş Milletler Çocuk Hakları Bildirisi hemen her ülke tarafindan kabul edilmiş 20. yy çocuk siyasetini yansıtan önemli belgelerdir. "Tüm asgari bir özen gösterilmelidir" ilkesini temel alan "Cenevre Çocuk Hakları Bildirgesi” ni, 1959 yılında BM Genel Kurulu kabul etmiştir. 1979 yılında ilan edilen "Dünya Çocuk Yıllı"nda başlayan çalışmalar, 20 Kasım 1989 tarihinde Birleşmiş Milletler Genel Kurulu'nda onaylanarak, 2 Eylül 1990 tarihinde yürürlüğe giren 1994 y1lında TBMM tarafından onaylanarak iç hukuk kurallarına dönüştürülen Çocuk Hakları Sözleşmesi uluslararası alandaki çok önemli belgelerden bir başkasıdır (Müftü, 1997; Akt. Yolcuoğlu, 2009, s. 45, 46; Canarslan, 2012, s. 436). Sözleşmenin temeli olarak; çocuğun yaşama, gelişme ve korunması hakkı, çocuğun öncelikli yararının gözetilmesi, çocuğun görüşünün alınması, ilkelerinin sadece sözde kalması değil uygulanması gerekmektedir. Sözleşme, çocuğun yaşama, korunma ve gelişimi açısından aileyi, birincil kurum olarak belirtmiştir. Sözleşmenin 5. maddesi, anne-baba sorumlulukları ve çocuğun ailesinden ayrılmadan, aile içerisinde desteklenmesinin önemini vurgulamaktadır. Ailenin ihtiyaçlarının karşılanması, ebeveynlik becerilerinin geliştirilmek, onların haklarını yok saymadan iyi birer ana-baba olarak kabullenmek ve kapasitelerini artırmak, mümkün olduğu kadar çocukları ailelerinden ayırmamak, ÇHS gereğince devletin görevlerindendir (Yolcuoğlu 2009, s. 46).

Çocuk Koruma Kanunu (2005)'in amacı: korunmaya muhtaç olan ya da suça sürüklenen çocukların korunması, haklarının ve esenliklerinin güvence altına alınması konularında usûl ve esasları belirlemektedir. Kanunda korunmaya muhtaç çocuklar hakkında alınacak tedbirler, suça sürüklenen çocuklar hakkında uygulanacak güvenlik tedbirlerinin usûl ve esasları, çocuk mahkemelerinin kuruluş, görev ve yetkileri hükümlerle belirtilmiştir. Tanım olarak "korunma ihtiyacı olan çocuk", Bedensel, zihinsel, ahlaki, sosyal ve duygusal gelişimi ile kişisel güvenliği tehlikede olan, ihmal veya istismar edilen ya da suç mağduru çocuğu belirtir. "Suça sürüklenen çocuk", kanunlarda suç olarak tanımlanan bir fiili işlediği iddiası ile hakkında soruşturma veya kovuşturma yapılan ya da işlediği fiilden dolayı hakkında güvenlik tedbirine karar verilen çocuğu belirtmektedir. Kurum ise kanun kapsamındaki çocuğun bakılıp gözetildiği, hakkında verilen tedbir kararlarının yerine getirildiği resmî veya özel kurumlardır. "Sosyal çalışma görevlisi" psikolojik danışmanlık ve rehberlik, psikoloji, sosyoloji, çocuk gelişimi, öğretmenlik, aile ve tüketici bilimleri ve sosyal hizmet alanlarında eğitim veren kurumlardan mezun olmuş elemanları belirtir (Erişim1).

Her toplumda ailesinin yanında türkü nedenlerle bakılamayan çocukların korunması, yetiştirilmesi konusu toplumun bir görevi olarak benimsenmiş ve bu amaçla devlet tarafindan gerek yasalarla ve gerekse hizmetlerle birtakım önlemler alınmıştır (İçağasığlu, 2001; Akt. Canarslan, 2012, s. 437).

Korunma ihtiyacı olan çocuklara sunulan hizmetler temelde iki kategoriye ayrılmaktadır. Bunlar; çocukların toplum içinde kendi ailesi veya başka bir ailenin yanında yaşamını devam ettirmesini sağlayan hizmet modelleri ve kurum bakımı hizmet modelleridir (Yıldırım.2007, s. 99).

\section{Türkiye'de Çocuk Koruma ve Bakım Sistemleri}

Ülkemizde çocukların korunması ile ilgili kurumların önde geleni Aile ve Sosyal Politikalar Bakanlığı Çocuk Hizmetleri Genel Müdürlügüuür. Çocuk Hizmetleri Genel Müdürlüğü sosyal hizmetler ve yardım uygulamalarıyla 'korunmaya muhtaç çocuklara' korunma ve bakım hizmetleri sunmaktadır. Bu koruma ve bakım hizmetleri aile destek hizmetleriyle çocukların aile yanında bakımı şeklinde olabileceği gibi, koruyucu aile uygulaması ve evlat edindirme uygulamaları aracılığıyla da sunulabilmektedir. Bazen de korunmaya muhtaç çocuklar kurum bakımına alınmakta çocuk yuvaları, yetiştirme yurtları, çocuk evlerinde bakım ve koruma hizmeti verilmektedir (Yazıc1, 2012, s. 500-501). Bu çalışmada dolaylı olarak da olsa çocuk koruma ve bakım hizmeti veren kurumlar da değerlendirmeye alınmıştır. Bunun nedeni 
Türkiye'de çocuklara yönelik bakım ve koruma hizmeti veren tüm kurumların ve hizmet modellerinin genel bir görünümünü sunmak ve değerlendirmesini yapmaktır.

\section{Kurum Bakımı Sağlayan Hizmet Modelleri \\ 1. Cocuk Yuvaları}

0-12 yaş arasındaki korunmaya muhtaç çocukların, bedensel, eğitsel, psiko-sosyal gelişimlerini, sağlıklı bir kişilik ve iyi alışkanlıklar edinebilmelerini sağlamakla görevli ve yükümlü sosyal hizmet kurumlarıdır. Gerekli görülen hallerde 12 yaşını tamamlamış olan korunmaya muhtaç kız çocukları da çocuk yuvalarında kalabilmektedir (Paslı, 2015, s. 79).

Çocuk yuvalarında; çocukların dinlenebilmeleri, televizyon izleyebilmeleri ve ders çalışabilmeleri için farklı bölümler de bulunmaktadır. Düzenlemelerde bu yuvaların, çocukların evi olduğu gerçeği dikkate alınarak bölümler rahat, donanımlı, yaşlarına uygun olarak yapılmaktadır. Ev ortamına benzer bir biçimde, oturma odaları, salonlar, banyolar, yatak odaları, mümkün olduğu kadar düzenli ve kaliteli hizmet prensibiyle yapılmaktadır. Ayrıca oyun bahçeleri, yeşil alanlar, kum havuzları, basket ve futbol sahaları da bulunmaktadır (Yildırım \& Y1ldırım, 2008, s. 210).

\section{Sevgi Evi}

Sevgi evleri; koğuş tipi kurum bakımının yerine daha küçük birimler içerisinde, aile ortamına benzeyen bir yap1 ve ilişki sistemi içinde 10-12 çocuğun kalabildiği, site içerisinde müstakil binalardan oluşan bir bakım projesidir. Ev ortamı biçiminde düzenlenen, görevlendirilen az sayıda personel ile sürekli ve değişmeyen bir bakım ve hizmetin sunulması amaçlanmaktadır. Böylelikle çocuklara temel güven duygusunun kazandırılması ve çocuklarda temel güven hedeflenmektedir. Sevgi evleri hizmeti; Çocuk Hizmetleri Genel Müdürlüğü Bakım Hizmetleri Daire Başkanlığının koordine ettiği devamlı yürütülen hizmettir (Erbay, 2015, s. 65).

2004 yılında 'Sevgi Evleri' projesi başlatılmıştır. Çocuğun sağlıklı bir şekilde gelişiminin sağlıklı bir aile yanında olabileceği gerçeğinden hareket edilerek, SHÇEK tarafından korunmaya muhtaç çocukların önce Koruyucu Aile, Evlat Edindirme, Ayni Nakdi Yardım hizmetlerinden yararlandırılması amaçlanmaktadır. 'Sevgi Evleri Projesi' ile çocukların toplu yaşamın getirdiği olumsuzlukları yaşamadan yetişebilecekleri kuruluşların yaygınlaştırılmasına yönelik çalışmalar büyük bir hızla devam etmektedir (Yıldırım \& Yıldırım, 2008, s. 211).

\section{Yetiştirme Yurtları}

13-18 yaş arasındaki korunma ihtiyacı olan çocukları koruma, çocuklara bakma ve çocukların bir iş veya meslek sahibi olmaları ve topluma faydalı bireyler olarak yetiştirilmelerini sağlamayla görevli ve yükümlü olan sosyal hizmet kurumlarıdır (Paslı, 2015, s. 78).

Aile ve Sosyal Politikalar Bakanlığg Çocuk Hizmetleri Genel Müdürlügü’ne bağlı olan 0-12 yaş arasındaki çocuklara hizmet veren kuruluşlar 'çocuk yuvası', 13- 18 yaş arasındaki çocuklara hizmet veren bakım kurumları olarak 'yetiştirme yurdu' olarak isimlendirilmektedir (Erbay, 2015, s. 64).

$\mathrm{Bu}$ yurtlar, çocukların ve gençlerin barınma, giyim ve beslenme ihtiyaçlarını, reşit olana kadar karşılar. $\mathrm{Bu}$ durum, korunma kararına neden olan koşulların ortadan kalkması durumunda, kurum yetkililerinin teklifiyle mahkeme tarafından çocuk reşit olmadan önce kaldırılabilir, reşit olduktan sonra da çocuğun rızasının alınması koşuluyla devam edebilir. Buna göre korunma kararı 18 yaşını bitirmiş olan korunmaya muhtaç çocuklar içerisinde, ortaöğretime devam edenler için 20 yaşına kadar, yüksek öğrenime devam edenler için ise 25 yaşına kadar uzatılabilmektedir. Ayrıca, öğrenimini sürdürmeyen 18 yaşını tamamlamış çocuklara iş ve meslek edindirmelerinin sağlanması ve kendisine yeter hale gelebilmesi için 20 yaşına kadar koruma kararı uzatılabilmektedir. Buna ek olarak da kız çocukları içinde evlenenlere çeyiz 
ihtiyaçlarını karşılamak üzere, en yüksek devlet memuru aylığının bir buçuk katı miktarda evlenmelerine yardım edilebilmektedir (Seyyar \& Genç, 2010, s. 849).

\section{Kadın Konukevi}

Kadın konukevleri; fiziksel, cinsel, duygusal ve/veya ekonomik şiddete maruz kalan veya böyle bir riski olan kadınlara, çocukları ile beraber şiddetten uzak, kendilerini güven olabilecekleri, ihtiyaçları hizmetleri belirlenen zaman dilimlerinde sağlayan yatılı sosyal hizmet kurumlarıdır (Erbay, 2015, s. 63).

Eşinden veya akrabalarından ağır baskı görmesi nedeniyle evinde yaşamını devam ettirmesi mümkün olmayan kadınların barındıkları ve sosyal hizmetler çerçevesinde geçici olarak korundukları yatılı ve ücretsiz evdir. Ülkemizde sosyal, ekonomik ve psikolojik sorunları olan kadınlar için açılmış olan sosyal hizmet merkezidir ve bu merkezde barınma süresi azami üç aydır. Bu süre içinde sağlık, sosyal ve ekonomik kökenli sorunlara çözüm bulunmaya çalış1ır eşiyle ve ailesiyle sorunları olan kadınların sorunlarının çözülmesine, sorunların çözülmemesi halinde hukuki sorunların çözülmesine yardımcı olunmaktadır. Bunun yanı sıra, kadınların kendi kendilerine yeterli hale gelebilmeleri için iş ve meslek sahibi olabilmeleri amaciyla gerekli çalışmalar yapılır (Seyyar \& Genç, 2010, s. 399).

Kadın konukevlerinde; aile içi şiddete uğrayan kadınların rehabilitasyonu ve sorunlarının çözümü için mesleki faaliyetler yürütülmektedir. Bu çalışmalar şunlardır:

-Şiddete maruz kalan kadınlarda şiddet sonucunda ortaya çıkan umutsuzluk, değersizlik, suçluluk, utanç ve korku gibi duygularıyla baş edebilme,

•Özgüvenin özsaygının yeniden yapılandırması,

-Yeni yaşam alternatiflerini sağlıklı bir biçimde saptayabilmeleri için psikolojik destek, danışmanlık, hukuksal rehberlik yapılması,

-Kendilerine yeter hale gelebilecekleri bir işe ve meslek kazanmaları için gerekli çalışmaların yapılması,

-Aile veya eşle bir araya gelme durumunun tercih edilmesi halinde ailenin şiddetten arınmış bir ortam olması ve çocukların şiddetten uzak, sağlıklı bir aile ortamında yetişebilmeleri için sağlıklı aile ilişkilerinin geliştirilmesi

- İzleme faaliyetlerinin devam ettirilmesi (Akbaş, 2015, s. 51).

Kadın konukevleri; eşler arasındaki anlaşmazlık nedeniyle evini terk eden veya eşleri tarafından terk edilen, bu nedenle yardım gereksinimi olan kadınlara hizmet vermektedir. Bunun yanında, fiziki, cinsel, duygusal ve ekonomik şiddete maruz kalanlar; boşanma ve eşin ölümü nedeniyle ekonomik ve sosyal zorluklar yaşayanlar; istenmedikleri evliliklere mecbur bırakılan kadınlar; evlilik dışı gebe kalan veya çocuk sahibi olan ve bu yüzden ailesi tarafindan istenmeyen kadınlar da konukevi hizmetinden yararlanmaktadır. Uyuşturucu madde, alkol bağımlısı olup, tedavi olmuş ve alışkanlıklarından kurtulmuş olanlar, cezaevinden yeni çıkan, yardım ve desteğe gereksinim duyan kadınlar ile kontrolleri dışında ortaya çıkan çevre şartları sebebiyle ekonomik ve sosyal yoksunluk içinde olan kadınlarda kadın konukevlerinde kalabilmektedirler (Yıldırım \& Yıldırım, 2008, s. 246).

\section{Gözlem Evleri}

Gezici sosyal hizmet ekipleri veya kamu, özel kurumlar veya kişilerce belirlenmiş ya da bildirilmiş sokakta yaşayan ve çalışan çocukların ön incelemelerini yapan ve giyim, beslenme, sağlık, temizlik ihtiyaçlarını karşılayan, gerekirse kısa süreli barınma hizmeti veren, aileler ile bağlantının kurulduğu, çocukların durum ve özelliklerine uygun kuruluşlarla işbirliğinin yapıldığı ve çocukların özelliklerine ve durumlarına göre uygun kurumlara havale işlemlerini yapan ilk müdahale merkezleridir (Pasl1, 2015, s. 78). 


\section{6. Çocuk Evleri}

Şehrin sosyal, kültürel ve fiziksel yapısı çocuğu yetiştirme için elverişli olan bölgelerinde, tercih olarak şehir merkezinde, okul ve hastane çevresindeki yerlerde bağışlanmış özellikle lojman olarak kullanılmış apartman dairesi veya müstakil dairelerde 0-18 yaş grubu 6-8 çocuğa bir ev ortamı oluşturularak korunma ve bakım hizmeti veren sosyal hizmet kuruluşlarıdır (Pasl1, 2015, s. 79).

Küçük gruplardan oluşacak şekilde çocukların bağımsız ortamlarda kendi dairelerinde hayatlarını devam ettirdikleri, bakım hizmeti aldıkları sosyal hizmet modelidir. Sosyal hizmet mevzuatına göre 0-18 yaş dilimi arasında hakkında korunma ve bakım tedbiri kararı bulunan korunmaya muhtaç çocukların kaldığı, çocukların hayatlarını rahat bir şekilde devam ettirebilecekleri, şehir merkezlerinde 5 veya 8 kişilik olarak düzenlenmiş ev ortamlı sosyal hizmet kuruluşlarıdır (Şeker, 2015, s. 16-17).

Toplumun sosyal, ekonomik ve kültürel yapısı hızlı değişmektedir (son yıllarda yaşanan gelir dağılımındaki dengesizlik işsizlik oranının artması, köyden kente göçle beraber sosyal ve ekonomik sorunlardaki artış) ve buna bağlı olarak korunma ihtiyacı olan çocuk sayısındaki artmaktadır, korunma ihtiyacı olan çocuklara verilen kurum bakımı modelinin yeniden yapılanması ihtiyacı ortaya çıkmıştır. Bu anlamda uygulanmaya başlanan ve yüksek öncelikte çocuğun yararına yönelik çocuk evleri ile ilin sosyal ve fiziksel yapısı dikkate alınarak çocuk yetiştirmek için elverişli bölgelerinde özellikle ilin merkezindeki okullar ve hastaneler çevresinde bağışlanmış lojman kullanımında apartman dairesi ya da müstakil daireler içinde 018 yaş arası 6-8 çocuğa ev ortamı oluşturularak koruma ile bakıma alınan bu çocukların bedensel ve psiko-sosyal gelişimlerinde, eğitimlerinde ve meslek edinerek topluma yarar sağlayan birey olmaları için yetiştirilmeleri amaçlanmaktadır (Erbay, 2015, s. 65).

\section{Koruma Bakım ve Rehabilitasyon Merkezleri}

Suça yönelen çocuk davranış bozukluklarını ortadan kaldırmak için rehabilitasyon süreci bitinceye kadar geçici bir süre ile bakım ve koruma sağlayan yatılı sosyal hizmet kuruluşlarıdır. $\mathrm{Bu}$ süreç içerisinde aile, yakın çevre ve toplum ile ilişkilerinin düzenlenmesi için çalışmalar yapılmaktadır. 7-18 yaş arası çocuklara için ayrı ayrı yapılandırılmış sosyal hizmet birimleridir (Pasl1, 2015, s. 77).

\section{Bakım ve Sosyal Rehabilitasyon Merkezleri}

Duygusal, cinsel ve/veya fiziksel istismara uğrayan çocuklara olumsuz hayat deneyimlerinin sonucu olan travma ve/veya davranış bozukluklarını gidermek için rehabilitasyon süreci tamamlanana kadar geçici süre bakım ve korunma sağlayan, bu süreçte aile, yakın çevre ve toplum ile ilişkilerinin düzenlemesi için çalışmaların yapıldığı, kız ve erkek çocuklar için ayrı ayrı yapılandırılmış yatılı sosyal hizmet kurumlarıdır. Bu merkezler mesleki çalışma yapılan ve üniversite veya devlet hastanelerinin psikiyatri servislerinden destek alınarak çocukların rehabilitasyonunun amaçlandığı birimlerdir. $\mathrm{Bu}$ kuruluşlarda rehabilitasyon sürecini tamamlayan çocuklar ailelerine (ailesi tarafından istismar edilmemişse) teslim edilir veya diğer sosyal hizmet kurumlarına yerleştirilir (Paslı, 2015, s. 78).

Duygusal, cinsel ve/veya fiziksel istismara uğrayan çocukların, olumsuz yaşam deneyimleri nedeniyle ortaya çıkan travma ve/veya davranış bozukluklarını gidermeye yönelik hakkında güvenlik tedbiri kararı alınmış çocukların 5395 sayılı Çocuk Koruma Kanunu gereği bakımı, eğitimi, rehabilitasyonu ve toplumla yeniden bütünleşebilmelerini sağlamak amacıyla, çocuk ve yetiştirme yurtlarından farklı, bakım ve barınma birimlerinin yapılandırılması zorunluluğu ortaya çıkmıştır. Bunun için yeni bir hizmet modeli olarak, çeşitli illerde istismara maruz kalan çocuklar için Bakım ve Sosyal Rehabilitasyon Merkezleri kurulmuştur (Erbay, 2015, s. 70). 


\section{Bakım ve Rehabilitasyon Merkezleri}

0-6 yaş grubu, 7-12 yaş grubu, 13-18 yaş grubu zihinsel engelli çocuklar için yatılı ve/veya gündüzlü bakım, rehabilitasyon ve danışmanlık sağlayan kurumlardır. Özel sektör bünyesinde verilen hizmetler ücrete tabidir (Pasl, 2015, s. 78).

Bakım ve rehabilitasyona ihtiyacı olan bireylerin sürekli-geçici bakımı ve/veya sosyal hayata yeniden kazandırılabilmeleri için hizmet veren özel veya kamuya ait yatılı sosyal hizmet kuruluşudur. Bedensel, zihinsel ve ruhsal engelleri sebebiyle normal yaşama uyum sağlayamayan bireylerin işlevsel kayıplarını gidermek ve toplum içinde kendilerine yeterli hala gelmelerini sağlayacak beceriler kazandırmak veya bu becerileri kazanamayanlara sürekli bakım hizmeti veren sosyal hizmet kuruluşlarıdır (Seyyar \& Genç, 2010, s. 90).

\section{0. Çocuk ve Gençlik Merkezleri/Sokakta Çalışan Çocuklar Merkezleri}

Çocuk ve gençlik merkezleri; eşler arası anlaşmazlık, ihmal, hastalık, kötü alışkanlık, yoksulluk, terk gibi sebeplerle sokağa düşen bu yüzden sosyal tehlikelere maruz kalan veya sokakta çalıştırılan 7-18 yaş arasındaki çocuk ve gençleri geçici süre ile rehabilite etmek ve topluma yeniden kazandırmak için hizmet veren yatılı ve gündüzlü sosyal hizmet kuruluşlarıdır (Paslı, 2015, s. 78). Bu merkezlerde çocuklara ve ailelere rehberlik, eğitim, rehabilitasyon hizmetleri verilmekte, okula gitmeyen çocuklar okula başlatılmakta, iş ve meslek edindirme programları uygulanmakta, çocuklar ailesinin yanına döndürülmekte, nüfusa kayıtlı olmayan çocukların kayıt işlemleri yapılmakta, beslenme, temizlik ve sağlık ihtiyaçlarının karşılanmasına yönelik hizmetler sunulmaktadır (Y1ldırım, 2007, s. 91).

Ebeveyn ihmali, eşler arası anlaşmazlık, aile içi şiddet, yoksulluk, hastalık ve terk gibi farklı sebeplerden dolayı sosyal tehlikelere maruz kalan çocuklar için kurulan yatılı veya gündüzlü sosyal hizmet kuruluşudur. Ülkemizde bu merkezlere geçici olarak yerleştirilen çocuklara psiko-sosyal rehabilitasyon ve topluma yeniden kazandırmaya yönelik hizmetler verilmektedir. Türkiye'de 'Çocuk Misafirhanesi' ismiyle ilk çocuk merkezi, 1990 y1lında İstanbul' da hizmete açılmıştır. Sokakta kalan, çocuklar için ilk çalışmalar burada yapılmıştır. Burada eğitim sürecinden geçen çocuklar, daha sonra ailelerine verilmekte veya kimsesi olmayan çocuklar yetiştirme yurtlarına yerleştirilmektedir (Genç \& Seyyar, 2010, s. 149).

Bu hizmet modeli; sokakta çalıştırılan, sokakta 24 saatini geçiren ve her türlü istismara açık olan, madde bağımlısı çocukların sokaktan kurtarılarak örgün ve mesleki eğitime yönlendirilmesini, madde bağımlılıklarının tedavi edilmesini, barınma, beslenme, giyim, sağlı, eğitim vb. tüm gereksinimlerinin karşılanmasını, toplumla yeniden bütünleştirilmesini içeren çok sektörlü bir yaklaşımdır. Bunun yanında çocukların sokağa düşmelerini önleyecek önlemler de barındırmaktadır (Erbay, 2015, s. 71).

\section{1. Çocuk Destek Merkezleri}

Suç kapsamında mağdur veya sürüklenen, sokakta yaşayan çocuklar için, akıl ve bilim rehberliğinde uluslararası standartlara uygun olarak ülkemizin şartlarında verilen destek hizmetleridir. Belirtilen çocuklar için bu merkezler çocuğun özellikleri dikkate alınarak değişik adlarla (Çocuk ve Gençlik Merkezleri, Koruma Bakım ve Rehabilitasyon Merkezleri ve Bakım ve Sosyal Rehabilitasyon Merkezleri) isimlendirilmiş, bu çocukların korunma anlayışında muhtaç ve mağdur durumlarına vurgu yapan; 19.02.2014 tarihinde Resmi Gazetede yayınlanarak yürürlüğe giren 6518 Sayılı Aile ve Sosyal Politikalar Bakanlığının Teşkilat ve Görevleri Hakkında Kanun Hükmünde Kararname ile Bazı Kanun ve Kanun Hükmünde Kararnamelerde Değişiklik Yapılmasına Dair Kanunda "Çocuk Destek Merkezi" adında isimlendirilmiştir. Çocuk Destek Merkezleri Yönetmeliği 29.03.2015 Tarih ve 29310 Sayılı Resmi Gazetede yayınmıştır. Bu çocuklara özgü Çocuk Destek Merkezleri Bakanlık tarafından kurulmaktadır. Destek merkezlerinde çocukların temel ihtiyaçlarını karşılamak, fiziksel, duygusal, psikolojik ve sosyal gereksinimlerini belirleyerek olası müdahaleleri yapmak, aile ve 
yakın çevrelerine dönmeleri veya diğer sosyal hizmet modellerine hazır olmaları için hizmet verilmektedir. Çocuk Destek Merkezlerinde çocukların rehabilitasyonunu gerçekleştirmek sonuncul amaç olup, bu süreçte çocuğun hayatını normal olarak devam ettirebilecek şekilde rehabilite edilmesi ve toplumla bütünleşmesi hedeflenmektedir. Verilen rehabilitasyon hizmetinin nitelikli ve özellikli oluşu süreçte ayrıntılı ve çözüme odaklı bir anlayışta hizmet gerektirmektedir. Bu amaç doğrultusunda öncelikli olarak çocukların istenmeyen davranışlara yönelmesine neden olan, koşulların belirlenmesi ve buna göre bir tedavi planının oluşturulması gerekmektedir (Erişim 2).

\section{II. Çocukların Bir Aile Yanında Bakımını Sağlayan Hizmet Modelleri 1. Evlat Edinme}

Çocuğun yüksek yararının gözetilerek yasal olarak evlat edinilmek için olan uygun bir çocuk ile evlat edinme uygun olan aile ve kişi arasında hukuki bağ ile çocuk-ebeveyn ilişkisinin kurulmasıdır. Ülkemizde evlat edinme süreci; Türk Medeni Kanununun 305'den 320'ye kadar maddeleri, çocukların korunması ve Ülkelerarası Evlat Edinme Konusunda İşbirliğine Dair Sözleşmenin Onaylanmasının Uygun Bulunduğu Hakkında Kanun, Küçüklerin Evlat Edinilmesinde Aracılık Faaliyetlerinin Yürütülmesine İlişkin Tüzük kapsamında yürütülmektedir (Erbay, 2015, s. 66).

Bir çocukla yapılan incelemeler sonucunda durumu evlat edinme için uygun olduğu belirlenen bir kişi ve ailesi ile hukuki bağlar oluşturularak çocuk ebeveyn etkileşiminde ilişki kurulmasıdır. Aile ortamında, yetişme imkanı olmayan çocukları bu imkanı sağlayan ve çocuğun fiziksel, zihinsel, duygusal güvenliğini koruyan önemli bir uygulamadır. Amaç biyolojik olmayan ailesi tarafından çocuğa sürekli bir aile, aileye ise çocuk hasretini giderme imkanı sağlamaktır (Şenocak, 2005, Akt. Doğru \& Saltalı, 2015, s. 249).

\section{Koruyucu Aile Uygulaması}

Farklı sebeplerle öz ailesi yanında bakımları bir süre için sağlanamayan çocukların kısa veya uzun süreli, anne-baba özelliklerini taşıyan ücretli veya gönüllü statüdeki uygun aile veya kişilerin yanında bakımlarının devlet denetiminde sağlandığı hizmet modelidir. (Erbay,2015, s. 66). Koruyucu aile bakımı, çocuğa öz ailesi tarafından bakılamadığı, çocuğun evlatlık olarak verilmesinin mümkün olmadığı veya uygun görülmediği hallerde bir aile yanına yerleştirilerek geçici veya sürekli olarak bakımının sağlanması uygulamasıdır (Üstüner, vd. 2005; Akt. Doğru \& Saltal1,2015, s. 243).

Koruyucu aile hizmeti uygulamasında amaç, çocuk için karmaşık ve sorunlu olan bir dönemde özenli davranılarak çocuğun bu dönemi zarar görmeden atlatmasına ve normal hayatını sürdürmesine yardımcı olmaktır. Koruyucu aile yanına yerleştirilen çocuklar; öz ailesi bulunan, öz ailesi tarafından bir süre için bakımı sağlanamayan, çeşitli nedenlerle evlat edinilme şansı olmayan, kız veya erkek, sağlıklı veya engelli, tek veya kardeş olup, koruyucu aile yanına yerleştirilmesi uygun olduğu sosyal çalışmacı tarafından belirlenen çocuklardır. Bu yasal çerçevede, haklarında korunma kararı alınmış çocuklar, öz ailesinden izin alınması gerekmeden uygun kuruluşlara veya koruyucu aile yanına yerleştirilebilir (Erbay, 2015, s. 66).

Koruyucu aile yanına en fazla 3 çocuk aynı anda yerleştirilebilmektedir. Koruyucu aile yanına yerleştirmede çocuk açısından en önemli etken çocuğun yaşıdır. Kesin bir yaş olmamakla beraber 13 yaşından küçük çocuklar koruyucu aile uygulaması için daha uygun bulunmaktadır (Bıyıkl1, 1983; Şenocak, 2005; Akt. Doğru \& Saltalı, 2015, s. 244).

\section{Aile Yanında Destek ve Aileye Dönüş Uygulaması}

Korunma kararı alınmadan ekonomik zorluklar içinde olan ve yapılan yardımla ailesi yanında bakımının sağlanabileceği korunmaya ihtiyacı olan çocuklar ile hakkında korunma kararı olup 
kurum içinde bakılan çocuklardan ailesi yanında bakılabilecek olanlar bu hizmetten faydalandırılmaktadır (Erbay, 2015, s. 69).

Temel ihtiyaçlarını karşılayamayan ve yaşamlarını en düşük seviyede dahi devam ettirmekte zorlanan kişi ve ailelere 'Ayni Nakdi Yardım Yönetmeliği' hükümleri çerçevesinde sosyal yardım hizmetleri yapılmaktadır. Sosyal Yardım; Yoksulluk içinde olup temel ihtiyaçlarını karşlayamayan ve yaşamlarını en düşük düzeyde dahi sürdürmekte zorluk çeken kişilere ve ailelere kaynakların yeterliliği ölçüsünde yapılan aynı ve nakdi yardımları içermektedir (Doğru \& Saltal1, 2015, s. 237).

Kurum bakımına alınan çocukların korunma altına alınma sebeplerinin başında, ailelerin ekonomik sorunları gelmektedir. Sosyal yardımların en önemli işlevi; kurumun öncelikli hedef grubu olan korunmaya muhtaç çocukların, kurum bakımına alınmasında ana nedenin ekonomik yetersizlik olması durumunda, bu çocukların korunma altına veya kuruma alınmadan sosyal yardımla desteklenerek ailenin dağılmasına engel olmak ve ailenin birlikte hayatlarını sürdürmelerine imkan tanımaktır. Bu hizmet muhtaç olmaları sebebiyle korunma kararı alınarak kurum hizmetlerinden faydalanmak isteyen çocukların korunması, bakımı ve yetiştirilmesine yönelik hizmetlerin mümkün olduğu kadar kendi aileleri içinde verilmesi amaçlanarak oluşturulmuştur (Erbay, 2015, s. 69).

\section{Aileye Aile İçinde Yardım Uygulaması}

Çeşitli sebeplerle, kurum bakımına alınması gerekli olduğu düşünülen çocukların veya ailesi yanından alınmadan destek verilmesi gereken çocukların, aile ilişkilerinin sağlıklı bir biçimde yeniden düzenlenmesine yönelik rehberlik ve danışmanlık hizmetleri verilmesi bu sayede ailede var olan sorunların çözülmesine yardım edilerek çocuğun ailesi içinde yaşamını devam ettirmesi amacıyla meslek elemanlarının niteliklerinin artırılması amacıyla yapılan eğitim çalışmalarını kapsamaktadır (Erbay, 2015, s. 70).

Tablo 1: Hizmet Verilen Çocuk Sayısı 2017 Verileri

\begin{tabular}{|c|c|c|}
\hline $\begin{array}{l}\text { YIL : } 2017 \\
\text { Aralık }\end{array}$ & Kuruluş Sayısı & $\begin{array}{c}\text { Bakılan Cocuk } \\
\text { Sayısı }\end{array}$ \\
\hline Cocuk Evleri Sitesi & 108 & 6.208 \\
\hline Cocuk Evleri & 1.195 & 6.341 \\
\hline Cocuk Destek Merkezi & 65 & 1.640 \\
\hline & 1.368 & 14.189 \\
\hline
\end{tabular}

\begin{tabular}{|l|r|}
\hline ÇOCUĞA YÖNELIK HiZMETLER & Cocuk Sayıları \\
\hline Kuruluş Bakımı Altında Bulunan & $\mathbf{1 4 . 1 8 9}$ \\
\hline Koruma Altına Alınmadan Aile Yanında Destek Verilen & $\mathbf{1 0 4 . 7 2 9}$ \\
\hline Aileye Döndürülen Çocuk (2005-2017) & $\mathbf{1 1 . 3 4 2}$ \\
\hline Toplam Evlat Edindirilen & $\mathbf{1 6 . 1 7 1}$ \\
\hline Koruyucu Aile Yanında Bakımı Sağlanan & $\mathbf{5 . 6 4 2}$ \\
\hline Koruyucu Aile Sayısı & $\mathbf{4 . 6 5 4}$ \\
\hline Özel Kreş ve Gündüz Bakım Evlerinde Ücretsiz Bakılan & $\mathbf{2 . 4 0 0}$ \\
\hline
\end{tabular}

(Erişim 3).

\section{SONUÇ}

Yaşanan hızlı toplumsal değişim süreci, çarpık kentleşme, kırsal bölgelerden kente göç, işsizlik, geleneksel aileden çekirdek aileye geçiş, yoksulluk bazı ailelerin bu değişime uyum sağlayamamasına, parçalanmış aile sayısının ve korunmaya muhtaç çocuk sayısının artmasına 
neden olmaktadır. Hızlı toplumsal değişmenin bazı aileler üzerindeki etkisi yıkıcı olmakta ve aileler parçalanmaktadır. Aile parçalanmaları, önemli toplumsal sorunların ortaya çıkmasına zemin hazırlamaktadır. Genel olarak toplumda, özel olarak ailede yaşanan sosyal sorunlar, çocukları ve onların gelişim sürecini olumsuz etkilemektedir. Çocuğun her yönüyle bir bütün olarak sağlıklı bir şekilde gelişmesi için gerekli ortamı ve koşulları sağlamak öncelikle ailenin görevi ve sorumluluğudur. Ancak yaşanan hızlı değişim ve onun yarattı̆̆ı sorunlar nedeniyle aile bu işlevini yerine getirmekte başarısız olmaktadır. Bu değişim sürecinin, aileler üzerindeki olumsuz etkilerini ortadan kaldırmak için gerekli çalışmalar yapılmalıdır. Ailelerin desteklenmesi ve güçlendirilmesine yönelik çalışmalara ağırlık verilmesi korunmaya muhtaç çocuklar sorunu ve diğer toplumsal sorunların ortaya çıkmasını önlemek için önemlidir. Bu konuda sürekli, sistemli ve bütüncül sosyal politikaların geliştirilmesi ve uygulamaya konulmasına ihtiyaç vardır. Aile ve çocuk refahı alanında sosyal politikaların geliştirilmesi sürecinde ilgili tüm kurum ve kuruluşların görüşlerinin alınması ve diğer ülke örneklerinin incelenip değerlendirilmesi, ülkemize özgü çocuk koruma ve bakım modellerinin geliştirilmesi için yararlı olacaktır.

Ülkemizde sosyal politika, sosyal hizmetler alanında ve sosyal çalışma disiplininde yaşanan sorunlar, aileyi ve buna bağlı olarak da çocukları olumsuz etkilemektedir. Sosyal hizmetler alanında istihdam edilen sosyal çalışmacı ve diğer personel sayısının yetersiz olması, bu personelin gerekli mesleki yeterliliğe ve tecrübeye sahip olmaması, bu alanda hizmet veren kurum ve kuruluşlar arasındaki eşgüdüm eksikliği, yapılan çalışmalarda konu ile ilgili diğer disiplinlerle gerekli işbirliğinin olmaması aile ve çocuk refahı alanında ki sorunlarda etkili ve kalıcı çözümler üretilmesine engel olmaktadır. Çocuklara hizmet veren sosyal hizmet kuruluşlarındaki personel sayısı artırılmalı ve bu kurumlara yapılan atamalarda çocuk refahı alanında lisansüstü eğitim almış uzman kişilerin istihdam edilmesine öncelik verilmelidir. Çocuk refahı alanında çalışan personeller içinde sosyal çalışmacıların önemli bir yeri vardır. Ancak ülkemizde çocuk refahı alanında çalışan sosyal çalışmacı sayısı yetersizdir ve bu personelin mesleki yeterliliği ve deneyimi konusunda önemli sorunlar bulunmaktadır. Ülkemizde uzun y1llar Hacettepe Üniversitesi Sosyal Hizmet Bölümü bu konuda lisans ve lisansüstü eğitim veren tek kurum olarak kalmıştır. Ülkemiz nüfusu dikkate alındığında, tek bir üniversitenin sosyal çalışmacı ve sosyal çalışma alanında akademisyen ihtiyacını karşılayamadığı açıktır. 2000' li yıllarda ise peş peşe sosyal hizmet bölümleri açılmıştır. Ancak alanda yetişmiş akademisyen yetersizliğinden dolayı bu bölümlerde çok farklı alanlardan gelen akademisyenler istihdam edilmiş ve uzmanlık alanı sosyal çalışma olmayan akademisyenlerin sosyal çalışma eğitimi vermesi ve sosyal çalışmacı yetiştirmesi gibi bir durum ortaya çıkmıştır. Bünyesinde sosyal çalışma alanında uzman tek bir akademisyen bile olmayan sosyal hizmet bölümleri bulunmaktadır. Bu bölümler sosyal çalışma alanında lisans ve lisansüstü eğitim vermektedir. Ülkemizde ki sosyal çalışmacı açığının bu şekilde kapatılmaya çalışılması, sosyal çalışma alanında niceliğin artmasına fakat niteliğin hızla düşmesine sebep olmuştur. Çocuk refahı alanında en önemli çalışanlardan biri olan ve çocuk hakkında önemli kararları ve çocuğa gerekli hizmetleri verecek olan sosyal çalışmacıların bir bölümünün bu konuda mesleki yeterliliğe sahip olup olmadığı tartışmalı bir durumdur. Ülkemizde sosyal çalışma bölümlerinin açılması ve eğitim vermesi konusunda acil bir reforma ihtiyaç vardır. Yeni bölüm açılmasının bazı şartlara bağlanması, bölümde ders verecek akademisyenlerden en az ikisinin sosyal çalışma kökenli olması, bu şartları sağlamayan bölümlerin kapatılması, daha az sayıda daha nitelikli öğrenci yetiştirmeye ağırlık verilmesi vb. düzenlemeler çocuk refahı alanında çalışacak personelin mesleki yeterliliğinin artırılmasında çok önemlidir. Çocuk koruma ve bakım hizmetlerinde çalışacak ara eleman yetiştirilmesi konusunda meslek yüksek okulları bünyesinde eğitim veren Çocuk Koruma ve Bakım Hizmetleri programlarının sayısının artırılması ve bu program öğrencilerinin bu çocuk refahı alanında hizmet veren kurumlarda staj ve yerinde uygulama yapmaları için düzenlemeler yapılmalıdır. Bu kurumlara yapılacak ara eleman 
atamalarında bu program mezunlarına öncelik verilmelidir. Çocuk refahı alanı sosyal hizmetler içerisinde özel bir çalışma alanıdır ve bu alanda çalışacak sosyal çalışmacıların ve diğer personelin çocuk refahı konusunda uzmanlaşmış olmaları çocuklara verilecek hizmetlerin kalitesinin ve niteliğinin artırılmasını sağlayacaktır.

Korunmaya muhtaç çocukların bakım ve korunmasında öncelikli olarak tercih edilmesi gereken evlat edindirme ve koruyucu aile uygulamaları ülkemizde başarısızdır. Toplumun bu uygulamalara karşı tutumu olumsuzdur ve bu uygulamalardan yararlandırılan çocuk sayısı çok düşüktür. Toplumun bu hizmetlere bakış açısını değiştirmek ve bu hizmetlerden yararlanan çocuk sayısını artırmak için gerekli eğitim ve rehberlik çalışmaları yapılmalıdır. Ülkemizde korunmaya muhtaç çocuk sayısı ve çocuk sahibi olmak isteyen aile, kişi sayısı bu kadar fazlayken evlat edindirilen çocuk sayısının bu kadar düşük olmasının nedenleri araştırılmalıdır. Ülkemizde son yıllardaki artışa rağmen evlat edindirme ve koruyucu aile uygulamasından yararlanan çocuk sayısı hala düşüktür. Korunmaya muhtaç çocuk sayısı ile kıyaslandığında özellikle evlat edinilen çocuk sayısı çok azdır. Toplumun evlat edindirme ve koruyucu aile bakımı konularında bilgilendirilmesi ve bu uygulamalara karşı olumlu bir tutum geliştirmesi için gerekli rehberlik ve eğitim çalışmaları yapılmalıdır.

Çocuk refahı ile ilgili sorunlar, aile refahı sorunları ile yakından ilişkilidir. Çocuk refahı alanında yaşanan sorunların büyük bir kısmı aileden kaynaklanmakta ve ailelere yönelik hizmetler doğrudan ve dolaylı olarak çocukları da etkilemektedir. Ailelere yönelik koruyucu ve güçlendirici sosyal politikalar, çocukların gelişimleri üzerinde olumlu etkiler oluşturacak ve çocukların ailelerinden ayrılmaları, korunmaya muhtaç hale gelmeleri gibi istenmeyen durumlar engellenebilecektir. Kurum bakımının olumsuz etkilerinin görülmesinin ardından tüm dünyada olduğu gibi öncelik çocukların mümkün olduğu kadar ailelerinden ayrılmadan bakım ve korunmalarının sağlanmasına verilmiştir. Çocuğun aile yanında desteklenmesi uygulamasında, Türkiye'de çocukların korunmaya muhtaç hale gelmesinde en önemli nedenin yoksulluk, ekonomik nedenler olduğu göz önüne alınarak yapılan maddi yardımların günümüz koşullarına göre artırılması gerekmektedir. Maddi yardımların yanı sıra aileye çocuk gelişimi ve eğitimi, aile içi sorunların çözümü için gerekli psikolojik desteğin sağlanması ve bu konuda gerekli eğitim ve rehberlik çalışmalarının yaygınlaştırılmasına ihtiyaç vardır.

Ülkemizde son dönemlerde Aile ve Sosyal Politikalar Bakanlığı'nın kurulmasıyla birlikte, aile ve çocuk refahı alanında olumlu gelişmeler kaydedilmesine rağmen, aileleri çeşitli zarar ve risklerden koruyacak ve güçlendirecek, aile parçalanmalarını önleyecek politikalara ihtiyaç vardır. Aile ile ilgili bütün koruyucu ve güçlendirici çalışmalar çocuk refahı alanında da olumlu gelişmeleri beraberinde getirecek ve çocukların her yönüyle bir bütün olarak sağlıklı bir şekilde gelişmesi için uygun ortamı hazırlayacaktır.

Bilgilendirme / Acknowledgement: Makale, 1. Uluslararası Eğitim ve Sosyal Bilimlerde Yeni Ufuklar (ICES-2018) 911 Nisan 2018 İstanbul - 1st International Congresses on New Horizons in Education and Social Science (ICES - 2018) 9 to 11 April 2018 Istanbul adlı kongrede sunuldu ve Alınbaş Üniversitesi tarafindan desteklendi.

\section{KAYNAKÇA}

AKBAŞ, E. (2015). AILE VE KADINA YÖNELIK SOSYAL HIZMET KURULUŞLARI. Sosyal Hizmet Kuruluşları, SARAY Matbacılık, Eskişehir, s.38-59.

AKTAŞ, CANSIZ, M. (2014). NiTEL VERI TOPLAMA ARAÇLARI. Eğitimde Bilimsel Araştırma Yöntemleri, 1. Baskı yeri: Ankara, Pegem Akademi, s. 363.

BAL, H. (2013). NiTEL ARAŞTIRMA YÖNTEMI. 1. Baskı yeri: Isparta, Fakülte Kitabevi Yayınları, s: 180.

CANARSLAN, H. (2012). ERKEN ÇOCUKLUK GELIŞIMI VE EĞiTIMI, PARADIGMA KITABEVI YAYINLARI. 2. Baskı, Eylül, Ankara, s. 436. 
CAROLEE, H. (2013). ERKEN ÇOCUKLUK EĞITIM VE BAKIM ORTAMLARINDA SOSYALLEŞME ÇALIŞMALARI IÇiN BíR MODEL. Erken Çocukluk Eğitim Ve Bakımında Akran İlişkileri, Nobel Akademik Yayıncılık, Ankara.

DOĞRU, YILDIRIM, S., SALTALI, DURMUŞOĞLU, N. (2015). KORUNMAYA MUHTAÇ ÇOCUKLAR. Eğiten Kitap, Ankara, s. 233-254.

ERBAY, E. (2015). SAĞLIK KURUM VE KURULUŞLARI. Sosyal Hizmet Kuruluşları, Eskişehir, s.118-148.

ERIŞiM

https://www.google.com.tr/url?sa=t\&rct=j\&q=\&esrc=s\&source=web\&cd=1\&cad=rja\&uact=8\&ved=0ahUKEwiup uLUqLjWAhUEIxoKHS5BAS4QFggIMAA\&url=http\%3A\%2F\%2Fwww.mevzuat.gov.tr\%2FMevzuatMetin\%2F1. 5.5395.pdf\&usg=AFQjCNGibOKFwXs1gB2A1d0skDMnsMYSeg 22.09.2017, 10:56.

ERişiM 2. Aile ve Sosyal Politikalar Bakanlığı, Çocuk Hizmetleri Genel Müdürlüğü http://cocukhizmetleri.aile.gov.tr/uygulamalar/cocuk-destek-merkezleri 15.05.2018, 16:04.

ERIşiM 3. Aile ve Sosyal Politikalar Bakanlığı, Çocuk Hizmetleri Genel Müdürlüğü http://cocukhizmetleri.aile.gov.tr/data/544e2899369dc318044059c3/2017.pdf 15.05.2018, 15:07.

KARASAR, N. (2009). BíLIMSEL ARAŞTIRMA YÖNTEMLERİ. 20. Basım yeri: Ankara, Nobel Yayın Dağıtım, s: 77.

KOŞAR, N. (1992), SOSYAL HIIZMETLERDE AilLE VE ÇOCUK REFAHI ALANI. MN Ofset, 2. Baskı, Kasım.

NSAMENANG, B. ÇEV. OLGAN REFIKA, (2013). KAMERUN'DA KARMA YAŞ GRUPLARININ ÖNEMI. Erken Çocukluk Eğitim Ve Bakımında Akran Ilişkileri, Nobel Akademik Yayıncılık, Ankara, s: 61.

PASLI, F. (2015). ÇOCUKLAR VE GENÇLERE YÖNELIKK SOSYAL HIZMET KURULUŞLARI. Sosyal Hizmet Kuruluşları, Eskişehir, s.62-85.

ROSENTHAL, M., GATT, L. ÇEV. DENIZ, Ü., (2013). KÜÇÜK ÇOCUKLARIN SOSYAL İLiŞKILERINI DESTEKLEMEDE ERKEN ÇOCUKLUK BAKICILARININ EĞiTiMi, Erken Çocukluk Eğitim Ve Bakımında Akran İlişkileri, Nobel Akademik Yayıncılık, Ankara, s. 113.

SARGIN, N., (2015). ÇOCUKLARDA RUH SAĞLIĞl. Eğitim Yayınevi, Konya, s. 43.

SEYYAR, A., GENÇ, Y. (2010). SOSYAL HIZZMET TERIMLERI. Sakarya Yayıncılık, Sakarya.

ŞEKER, A. (2015). SOSYAL ÇALIŞMA VE SOSYAL HIZMETLER CEP SÖZLÜĞÜ. SABEV Yayınları, Ankara.

WOLFF, S. (2009). PROBLEM ÇOCUKLAR VE TEDAVI. Say Yayıncılık, İstanbul.

YAZICI, E. (2012). KORUNMAYA MUHTAÇ ÇOCUKLAR VE ÇOCUK EVLERI. Mustafa Kemal Üniversitesi Sosyal Bilimler Enstitüsü Dergisi, S.18, s. 500-524.

YILDIRIM, K. (2007). SOSYAL HIZMET. Sakarya Yayıncılık, İstanbul.

YILDIRIM, N., YILDIRIM, K. (2008). SOSYAL HIZMETE GIRIŞ. Sakarya Yayıncılık, İstanbul.

YILDIRIM, Ş. (2017). 2000'Li YILLARDA ÇOCUK KORUMA SISTEMI IÇINDE BAKIM HIZMETLERININ GENEL GÖRÜNÜMÜ. Manisa Celal Bayar Üniversitesi Sosyal Bilimler Dergisi, 15 (1), 87-110.

YOLCUOĞLU, GALIP, I. (2009). TÜRKIYE'DE ÇOCUK KORUMA SISTEMININ GENEL OLARAK DEĞERLENDİRILMESİ. Aile ve Toplum, Yıl.11, S.18, s.43-57.

YOLCUOĞLU, GALIP, İ. (2013). EBEVEYN BAKIMINDAN YOKSUN ÇOCUKLAR VE SOSYAL HIZMET. Sosyal Politika ve Kamu Yönetimi Bileşenleriyle Sosyal Hizmet Temelleri ve Uygulama Alanları, Ankara, 155169. 